\title{
ТЕОРЕТИКО-МЕТОДОЛОГІЧНІ ОСНОВИ ПОНЯТТЯ ГОСПІТАЛЬНОГО ОКРУГУ У СФЕРІ ОХОРОНИ ЗДОРОВ'Я
}

\author{
Гбур 3. В., Стовбан М. П.
}

\section{ВСТУП}

В сучасних умовах суспільного життя якісна медицина виступає ключовою метою функціонування сфери охорони здоров'я у країні, при цьому виступаючи базовим критерієм іï діяльності. В багатьох країнах прийняті спеціальні програми та концепції по реформуванню галузі охорони здоров'я, які в подальшому слугуватимуть основою для розробки національної політики в цій сфері, що, своєю чергою, $є$ вихідним пунктом у приведенні медичної галузі до успішної та такої, яка здатна забезпечити потреби пацієнтів на високому рівні. Не $\epsilon$ винятком й Україна, яка протягом останніх років особливо активно здійснює реформування системи охорони здоров'я.

Багато кроків на сьогодні вже зроблено, проведено повноцінне реформування первинної ланки надання медичних послуг, що дозволило практично реалізувати принцип “гроші ідуть за пацієнтом", і як наслідок, спричинило підвищення фінансування пріоритетних закладів охорони здоров'я з найбільшим оборотом пацієнтів, проте до кінцевої мети ще надзвичайно далеко. Одним із кроків подальшої оптимізації сфери охорони здоров'я є створення госпітальних округів, що $\epsilon$ новою практикою для нашої держави, а отже, зумовлює актуальність проведення даного дослідження.

Проблеми вдосконалення медичної сфери за допомогою формування госпітальних округів у зв'язку 3 новизною досліджено лише кількома науковцями протягом останніх декількох років. Так, дослідженню цієї тематики присвячені праці Устинова А.В., Зелезняк О.М., Мартишин О.О., Скрипник О.П., Калашник П.І., Варвянської С.В. та інших.

Проблематиці формування госпітальних округів присвячено роботи Лейберюк О.М., Бабінець Л.С., Богайчук В.Г., Боровик I.О., Ткач О.О., Матюк Л.М., Булах І.В., Західна О.Р., Мидлик Ю.І., Качур О.Ю., Мамчин М.М., Парій В.Д., Рощин Г.Г., Мазуренко О.В., Дорош В.М., Пагава О.З., Іванов В.І.

Бабінець Л.С., Богайчук В.Г., Боровик I.О., Ткач О.О., Матюк Л.М. визначили основні виклики системі охорони здоров'я в умовах 
децентралізації, пріоритету первинної медичної допомоги й утворення госпітальних округів, розглянувши досвід Тернопільської області.

Окрім того, дотичні питання організації госпітальних округів висвітлюються у працях таких вчених як Стеценко С.М., Романенко О.Д., Чугунова I.P. Проте поширення практики утворення госпітальних округів в областях України в межах проведення медичної реформи вимагає більш грунтовного висвітлення, що, перш за все, пов'язано із прийняттям наприкінці 2019 року Постанови Кабінету Міністрів України (КМУ) “Деякі питання створення госпітальних округів"1, якою внесено суттєве коригування до цього процесу. Метою нашого наукового дослідження $\epsilon$ визначення теоретичних та методологічний засад функціонування госпітальних округів у сфері охорони здоров'я, вивчення порядку їх створення та специфіки діяльності.

\section{1. Поняття госпітального округу та структура законодавства з питань створення госпітального округу}

Надання інтегрованих й економічно ефективних послуг - одна зі стратегій реформи, яка була прийнята в багатьох країнах Європи. Вона полягала в тому, щоб інтегрувати клінічні послуги на всіх ланках - від первинної медичної (або амбулаторної) до стаціонарної допомоги. Інтеграція - це така концепція економіки й оперативного управління, при якій усі складники системи надання медичної допомоги переслідують загальні інтереси й цілі. Інтегрована система надання медичної допомоги охоплюе механізми поділу фінансової відповідальності між постачальниками й управління ризиками ${ }^{2}$.

Інтеграція медичної допомоги в Україні відбувається шляхом формування госпітальних округів. Створення госпітальних округів $\epsilon$ одним із важливих напрямів реформування системи охорони здоров'я, наближення медичної послуги до людини та підвищення якості медичного обслуговування. Забезпечення їх ефективного функціонування та управління ними можливе на основі врахування таких відправних детермінант ${ }^{3}$ :

1 Постанова КМУ № 1074. Деякі питання створення госпітальних округів. Верховна Рада України. Офіційний сайт. Нормативні акти. URL: https://zakon.rada.gov.ua/laws/show/1074-2019-\%D0\%BF (дата звернення 24.02.2020).

2 Охорона здоров'я. У Харківській області створено госпітальний округ : вебсайт. URL: https://www.auc.org.ua/novyna/u-harkivskiy-oblasti-stvoreno-gospitalnyy -okrug (дата звернення 24.02.2020).

3 Постанова КМУ № 1074. Деякі питання створення госпітальних округів. Верховна Рада України. Офіційний сайт. Нормативні акти. URL: https://zakon.rada.gov.ua/laws/show/1074-2019-\%D0\%BF (дата звернення 24.02.2020). 
1) ефективність госпітальних округів визначається їх розвитком як динамічних адаптивних функціональних систем, зорієнтованих на виклики й вимоги середовища їх функціонування й об'єктивізацію мережі закладів охорони здоров'я та переліку медичних послуг, які вони надаватимуть;

2) широке коло учасників госпітальних округів зумовлює необхідність запровадження дієвих форм партнерської взаємодії при виробленні і прийнятті стратегічних рішень щодо їх розвитку;

3) управлінська й фінансова автономія закладів охорони здоров'я відкриває значні можливості підвищення якості медичного обслуговування, які можуть бути реалізовані за умови запровадження прогресивних форм i методів надання медичних послуг та налагодження взаємодії з усіма стейкхолдерами ${ }^{4}$.

Основними принципами модернізації $є$ узгодження єдиного понятійного простору, сімейний лікар має стати головною ланкою медичної допомоги, маршрутизація пацієнта, підвищення рівня усвідомленості та інформування пацієнта. У більшості закладів охорони здоров'я немає достатніх спроможностей для надання якісної медичної допомоги вторинного рівня. Це стосується обладнання, кадрів, інфраструктури. Без структурних та системних змін у розвитку мережі закладів охорони здоров'я бюджетні кошти будуть і далі витрачатися неефективно, а ресурси розподілятимуться нераціонально. У результаті це спричинятиме дефіцит якісних медичних послуг на місцевому рівні. Визначення лікарень інтенсивного лікування та формування національного стратегічного плану зробить серйозний внесок у вирішення цих проблем ${ }^{5}$.

В Україні у 2017 році розпочався процес створення госпітальних округів 3 метою оптимізації кількості та якості державних медичних закладів і покращення системи медичного забезпечення ${ }^{6}$. Це значить,

4 Постанова КМУ № 1074. Деякі питання створення госпітальних округів. Верховна Рада України. Офіційний сайт. Нормативні акти. URL: https://zakon.rada.gov.ua/laws/show/1074-2019-\%D0\%BF (дата звернення 24.02.2020).

${ }^{5}$ Устинов А.В. Госпітальні округи: МО3 представило методологію визначення лікарень інтенсивного лікування. Український медичний часопис : вебсайт. URL: https://www.umj.com.ua/article/136615/gospitalni-okrugi-moz-predstavilo-metodologiyuviznachennya-likaren-intensivnogo-likuvannya (дата звернення 25.02.2020).

${ }^{6}$ 10. Розпорядження КМУ № 23-Р “Про затвердження переліку опорних закладів охорони здоров'я у госпітальних округах на період до 2023 року”. Верховна Рада України. Офіційний сайт. Нормативні акти. URL: https://www.kmu.gov.ua/npas/prozatverdzhennya-pereliku-opornih-zakladiv-ohoroni-zdorovya-u-gospitalnih-okrugah-naperiod-do-2023-roku-23-150120 (дата звернення 24.02.2020). 
що зараз продовжується географічне формування меж госпітальних округів, а на відповідальність громад покладено функцію вирішення розвитку мереж лікарень для формування системи якісної медичної допомоги. 3 листопада 2018 по січень 2019 року семінари пройшли у 9-ти областях України, де сформовані госпітальні округи: Кіровоградська, Житомирська, Чернігівська, Вінницька, Хмельницька, Чернівецька, Одеська, Херсонська та Львівська області ${ }^{7}$.

В науковій літературі під госпітальним округом (ГО) розуміють об'єднання медичних закладів у єдину мережу в межах одного регіону для забезпечення принципу доступності, з урахуванням кількості населення певного регіону, наявної мережі медичних установ та транспортного сполучення ${ }^{8} .27$ листопада 2019 року урядом затверджено новий механізм формування госпітальних округів, згідно з яким до категорії госпітального округу включено вторинну (спеціалізовану) ланку, а також екстрену медичну допомогу в частині госпіталізації. Таким чином, відповідно до Постанови Кабінету Міністрів України “Деякі питання створення госпітальних округів” за № 1074 від 27 листопада 2019 року, госпітальним округом є функціональне об'єднання закладів охорони здоров'я, розміщених на відповідній території, що забезпечує надання вторинної (спеціалізованої) та госпітального етапу екстреної медичної допомоги населенню такої території.

Проте процес запровадження госпітальних округів в Україні розпочався ще задовго до прийняття вищенаведеної постанови i включав прийняття низки законів та постанов. Дослідимо детальніше кожен із них і наочно відобразимо на рис. 1. Отже, визначимо роль кожного з вищенаведених документів у процесі створення госпітальних округів. Загалом, вважається, що створення госпітальних округів уперше визначено вищезазначеним законом, ще в 1992 році, але на практиці цей процес розпочався значно пізніше, а саме - прийняттям розпорядженням Кабінету Міністрів України № 1013-р, згідно з яким було визначено основні напрями реформування та оптимізації сфери

${ }^{7}$ Устинов А.В. Госпітальні округи: МОЗ представило методологію визначення лікарень інтенсивного лікування. Український медичний часопис : вебсайт. URL: https://www.umj.com.ua/article/136615/gospitalni-okrugi-moz-predstavilo-metodologiyuviznachennya-likaren-intensivnogo-likuvannya (дата звернення 25.02.2020).

8 Інформаційне агентство Інтерфакс Україна. Уряд України санкціонував укрупнення госпітальних округів до обласного рівня : вебсайт. URL: https://ua.interfax.com.ua/news/pharmacy/627086.html (дата звернення 24.02.2020).

9 Постанова КМУ № 1074 “Деякі питання створення госпітальних округів". Верховна Рада України. Офіційний сайт. Нормативні акти. URL: https://zakon.rada.gov.ua/laws/show/1074-2019-\%D0\%BF (дата звернення 24.02.2020). 
охорони здоров'я на шляху до підвищення якості послуг, які надаються медичним установами за рахунок пропорційного їх фінансування, відповідно до кількості пацієнтів ${ }^{10}$.

\begin{tabular}{|c|}
\hline $\begin{array}{c}\text { Структура законодавства з питань створення } \\
\text { госпітальних округів }\end{array}$ \\
\hline $\begin{array}{l}\text { 1. Закон України “Основи законодавства України про охорону здоров’я”, } \\
1992 \text { рік. }\end{array}$ \\
\hline $\begin{array}{l}\text { 2. Розпорядження КМУ № 1013-р “Про схвалення концепції реформи } \\
\text { фінансування системи охорони здоров’я”, } 2016 \text { рік. }\end{array}$ \\
\hline $\begin{array}{l}\text { 3. Постанова КМУ № } 932 \text { “Про затвердження порядку створення } \\
\text { госпітальних округів", } 2016 \text { рік. }\end{array}$ \\
\hline $\begin{array}{l}\text { 4. Наказ Міністерства охорони здоров’я України (МО3) № } 165 \text { “Про } \\
\text { затвердження примірного положення про госпітальний округ”, } 2017 \text { рік. }\end{array}$ \\
\hline $\begin{array}{l}\text { 5. Постанова КМУ № } 1074 \text { “Деякі питання створення госпітальних } \\
\text { округів”, } 2019 \text { рік. }\end{array}$ \\
\hline $\begin{array}{l}\text { 6. Розпорядження КМУ № 23-Р “Про затвердження переліку опорних } \\
\text { закладів охорони здоров’я в госпітальних округах терміном до } \\
2023 \text { року”, } 2020 \text { рік. }\end{array}$ \\
\hline
\end{tabular}

Рис. 1. Структура законодавства

3 питань створення госпітальних округів

Джерело: власна розробка автора на основі вказаного джерела ${ }^{11}$

Госпітальні округи в цьому процесі мають на меті оптимізувати діючу мережу медичних закладів із подальшим їх укрупненням та

10 Розпорядження КМУ № 1013-р “Про схвалення концепції реформи фінансування системи охорони здоров'я” зі змінами та доповненнями станом на 30.11.2016 року. Верховна Рада України. Офіційний сайт. Нормативні акти. URL: https://zakon.rada.gov.ua/laws/show/1013-2016-\%D1\%80 (дата звернення 24.02.2020).

11 Мартишин О.О. Госпітальні округи в Україні: проблеми та шляхи їх вирішення. Український медичний часопис : вебсайт. URL: https://www.umj.com.ua/ article/108816/gospitalni-okrugi-v-ukrayini-problemi-ta-shlyahi-yih-virishennya (дата звернення 24.02.2020). 
закриттям тих, витрати на утримання яких $\epsilon$ невиправданими через брак пацієнтів. Логічним продовженням цього процесу $є$ прийняття Постанови КМУ № $932^{12}$ та Наказу МО3 ${ }^{13}$, згідно $з$ якими вперше на практиці визначено особливості формування госпітальних округів, специфіку створення та функціонування госпітальних рад, а також їх роль у розробці плану подальшого розвитку ГО.

Заключним на момент дослідження законодавчим актом, щодо розгортання мережі госпітальних округів в Україні, є Постанова КМУ № 1074, в якій усунено неточності попередніх нормативних актів, а також запроваджено укрупнення наявних госпітальних округів та запропоновано оновлений порядок формування госпітальної ради ${ }^{14}$.

Створення госпітальних округів має на меті гарантувати пацієнтам своєчасний доступ до послуг медичних закладів, у той же час забезпечуючи максимальну якість медичної допомоги за умови раціонального та ощадливого використання ресурсів держави. На виконання вищеописаної вимоги урядом прийнято розпорядження, згідно 3 яким в найближчі три роки планується розгорнути мережу опорних лікарень як гарантії отримання всіма пацієнтами своєчасного комплексного спектру медичних послуг ${ }^{15}$.

\section{2. Основні принципи створення госпітальних округів}

У той же час постановою КМУ визначається, що створення госпітальних округів повинно грунтуватися на таких принципах (рис. 2). Важливим фактом, на якому наголошується в Постанові КМУ № 1074, є твердження про те, що госпітальний округ не є окремим організаційно-правовим рівнем діяльності виконавчої влади, а також не

12 Постанова КМУ № 932 "Про затвердження порядку створення госпітальних округів” (Постанова втратила чинність на підставі Постанови КМ № 1074 від 27.11.2019) Верховна Рада України. Офіційний сайт. Нормативні акти. URL: https://zakon.rada.gov.ua/laws/show/932-2016-\%D0\%BF (дата звернення 24.02.2020).

13 Наказ Міністерства охорони здоров’я України № 165 “Про затвердження примірного положення про госпітальний округ”. Сайт Міністерства охорони здоров'я. URL: $\quad$ https://moz.gov.ua/article/ministry-mandates/nakaz-moz-ukraini-vid-18122017-1621pro-vnesennja-zmin-do-primirnogo-polozhennja-pro-gospitalnij-okrug (дата звернення 24.02.2020).

14 Постанова КМУ № 1074 “Деякі питання створення госпітальних округів”. Верховна Рада України. Офіційний сайт. Нормативні акти. URL: https://zakon.rada.gov.ua/laws/show/1074-2019-\%D0\%BF (дата звернення 24.02.2020).

15 Розпорядження КМУ № 23-Р “Про затвердження переліку опорних закладів охорони здоров'я у госпітальних округах на період до 2023 року”. Верховна Рада України. Офіційний сайт. Нормативні акти. URL: https://www.kmu.gov.ua/npas/prozatverdzhennya-pereliku-opornih-zakladiv-ohoroni-zdorovya-u-gospitalnih-okrugah-naperiod-do-2023-roku-23-150120 (дата звернення 24.02.2020). 
$\epsilon$ окремою юридичною особою чи суб'єктом господарювання ${ }^{16}$. При цьому склад госпітального округу формується 3 органів, яким надано повноваження керувати закладами охорони здоров'я державної та комунальної власності, а також за погодженням керівників приватних медичних закладів, яким надано обов'язок забезпечувати надання вторинної та екстреної медичної допомоги в частині проведення госпіталізації в межах всіх адміністративно-територіальних одиниць України. Перелік госпітальних округів затверджується КМУ шляхом ухвалення відповідного розпорядження. Центром госпітального округу обирається населений пункт, який територіально є найближчим до центру ГО. При цьому в певному населеному пункті повинна бути багатопрофільна лікарня інтенсивного лікування другого рівня i кількість населення повинна становити понад 40 тисяч осіб.

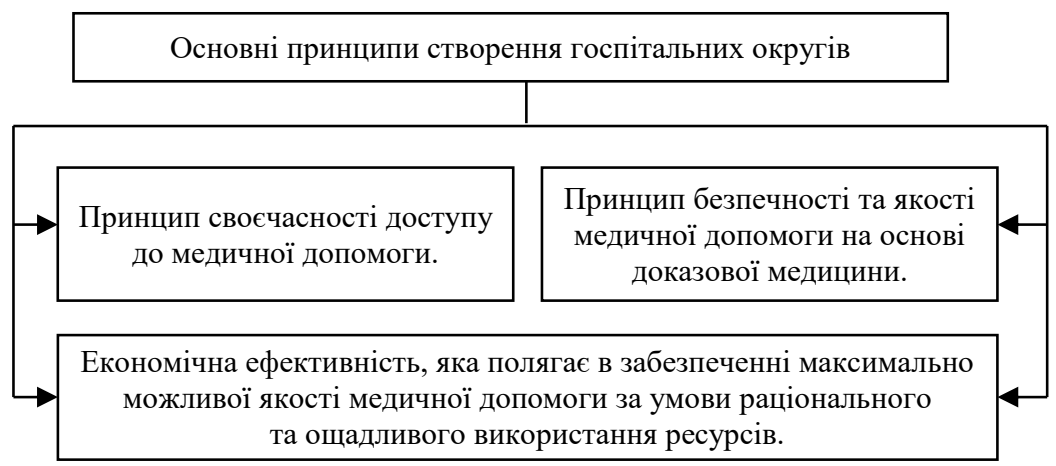

Рис. 2. Принципи створення госпітальних округів

Джерело: власна розробка автора на основі зазначеного джерела ${ }^{17}$.

3 метою ефективного управління госпітальним округом, визначення проблемних питань його функціонування, внесення пропозицій по вдосконаленню діяльності госпітального округу, формування напрямів його розвитку на перспективу при обласних державних адміністраціях створюються госпітальні ради. Учасниками госпітальної ради можуть бути представники облдержадміністрацій, керівники комунальних та

16 Постанова КМУ № 1074 “Деякі питання створення госпітальних округів”. Верховна Рада України. Офіційний сайт. Нормативні акти. URL: https://zakon.rada.gov.ua/ laws/show/1074-2019-\%D0\%BF (дата звернення 24.02.2020).

17 Постанова КМУ № 1074 “Деякі питання створення госпітальних округів”. Верховна Рада України. Офіційний сайт. Нормативні акти. URL: https://zakon.rada.gov.ua/ laws/show/1074-2019-\%D0\%BF (дата звернення 24.02.2020). 
державних медичних закладів, а також члени об'єднань профспілок, громадських організацій та керівники приватних медичних закладів за ïx згодою. Проте остаточна кількість учасників госпітальної ради в підсумку залежить від кількості адміністративно-територіальних одиниць, які входять до госпітального округу, кількості населення в ній та в госпітальному окрузі зокрема. При цьому робота госпітальної ради повинна грунтуватись на принципах колегіальності та відкритості у прийнятті рішень, прозорості діяльності та рівноправності іiі членів. Окрім вищеперерахованих функцій, на госпітальну раду та обласні державні адміністрації накладається обов'язок розробки та прийняття плану розвитку госпітального округу на найближчі $3-5$ років. Типова його структура включає елементи, зображені на рис. 3 .

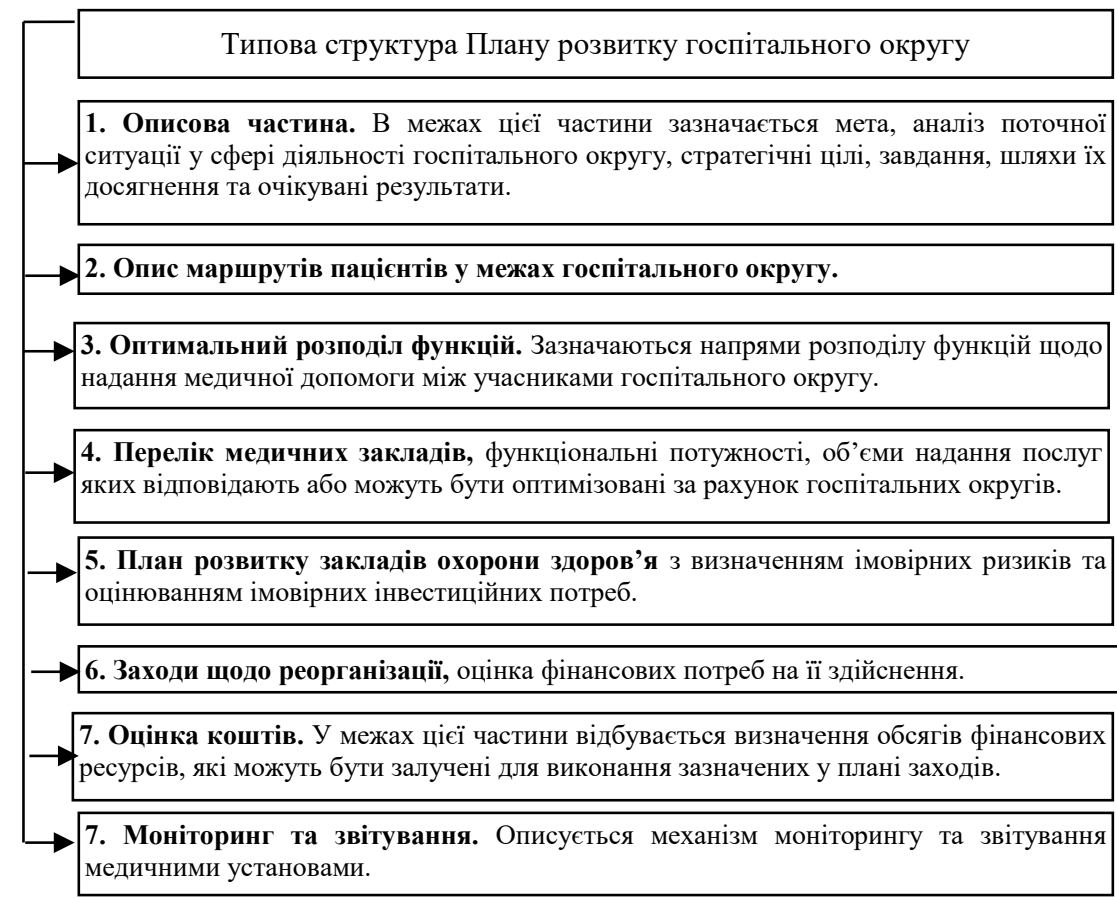

Рис. 3. Типова структура Плану розвитку госпітального округу Джерело: власна розробка автора на основі зазначеного джерела ${ }^{18}$.

18 Постанова КМУ № 1074 “Деякі питання створення госпітальних округів”. Верховна Рада України. Офіційний сайт. Нормативні акти. URL: https://zakon.rada.gov.ua/ laws/show/1074-2019-\%D0\%BF (дата звернення 24.02.2020). 
3 вищенаведеного бачимо, що розробка Плану розвитку госпітального округу багатокомпонентний процес, який вимагає залучення висококваліфікованих спеціалістів, що, своєю чергою, може значною мірою позначитися на правильності його складання. Адже до процесу його створення залучаються не професійні аналітики та аудитори, а особи зі сформованого складу обласних державних адміністрацій та керівники медичних закладів.

В подальшому це може відобразитись у низькій ефективності поданих планів, і віддаленості їх від реальної ситуації, що вже неодноразово відбувалось при реформуванні медичної галузі. По завершенню періоду, під час якого розробляється план розвитку госпітального округу, госпітальною радою готується звіт по результатах його впровадження, а також План розвитку госпітального округу на новий період.

\section{3. Структурний склад госпітальних рад, які створені в регіонах}

Щодо реальної ситуації в регіонах, то за даними дослідження не всі сформовані госпітальні ради дотримуються встановленого постановою КМУ № 1074 порядку залучення учасників до ії складу. В окремих округах відстежувалась проблема залучення до роботи госпітальної ради більшої кількості осіб за розрахункову, що значно гальмувало іiі створення, а деякі госпітальні ради взагалі почали свою діяльність із перевищенням допустимої кількості учасників.

Окрім того, структурний аналіз складу госпітальної ради виявив, що в деяких регіонах не дотримуються вимог Міністерства охорони здоров'я щодо спеціальності учасників, залучаються особи, які ніяк не пов'язані 3 медициною. Близько 56\% членів госпітальних рад $\epsilon$ лікарями або працівниками органів місцевого самоврядування в частині підрозділів, які відповідають за забезпечення реалізації державної та регіональної політики в галузі охорони здоров'я.

Законодавством передбачено, що пропозиції, напрацьовані госпітальною радою, затверджуються місцевими радами-членами відповідного госпітального округу. Їм надана рекомендація розглядати рішення госпітальних рад протягом двох тижнів після їх прийняття. Проте ані Примірне положення про госпітальних округ, запропоноване MO3, ані щойно прийнята постанова КМУ не враховують особливостей процедури прийняття рішення місцевою радою, що передбачено діючим законодавством, а, навпаки, нехтують фактом обов'язкового оприлюднення проєкту рішення на сайті відповідної місцевої ради, а також необхідністю погодження його постійно діючою комісією. Практична реалізація механізму функціонування госпітальних округів 
відбувається через консолідацію функцій медичних установ одного регіону. При цьому у структурі одного госпітального округу повинні здійснювати свою діяльність багатопрофільні лікарні інтенсивного лікування першого та другого рівнів, які повинні забезпечувати надання лікарської допомоги не менше як 120 тисячам осіб та 200 тисячам осіб відповідно. Обов'язковою умовою при цьому $\epsilon$ забезпечення доступу пацієнтів до отримання медичної допомоги за час, який не перевищує 60 хвилин.

У той же час необхідно враховувати те, що об'єднання лікарень - це справа не одного дня, а отже, необхідно забезпечити населення доступом до медичних установ на час такого укрупнення. Із цією метою у структурі госпітальних округів створюються опорні лікарні, період діяльності яких розрахований на три роки. На виконання цього пункту в січні 2020 року прийнято Постанову КМУ № 23-р “Про затвердження переліку опорних закладів охорони здоров'я у госпітальних округах на період до 2023 року”, якою визначається перелік опорних лікарень у межах кожної області ${ }^{19}$.

Процес реального створення госпітальних округів в Україні розпочався ще у 2017 році, після затвердження урядом України відповідного порядку наприкінці 2016 року. Проте на той час представниками місцевої влади наголошувалось, що критерії створення госпітальних округів чітко не визначені, що в кінцевому підсумку може спровокувати спекуляції. Окрім того, ними було висловлено стурбованість тим, що новоутворені госпітальні округи не будуть збігатись із адміністративно-територіальним устроєм, утвореним у результаті адміністративно-територіальної реформи. Тим не менше, утворення госпітальних округів розгорнулось на повну силу, і вже наприкінці 2019 року мало такий вигляд (рис. 4).

Таким чином, як можемо побачити на рисунку, госпітальні округи створені практично у всіх областях України, крім Закарпатської, а також частини Донецької, Луганської областей та Автономної Республіки Крим. Найбільше госпітальних округів утворено в Одеській, Донецькій, Запорізькій, Сумській та Черкаській областях, а найменше у Львівській та Харківській.

${ }^{19}$ Розпорядження КМУ № 23-Р “Про затвердження переліку опорних закладів охорони здоров'я у госпітальних округах на період до 2023 року”. Верховна Рада України. Офіційний сайт. Нормативні акти. URL: https://www.kmu.gov.ua/npas/prozatverdzhennya-pereliku-opornih-zakladiv-ohoroni-zdorovya-u-gospitalnih-okrugah-naperiod-do-2023-roku-23-150120 (дата звернення 24.02.2020). 


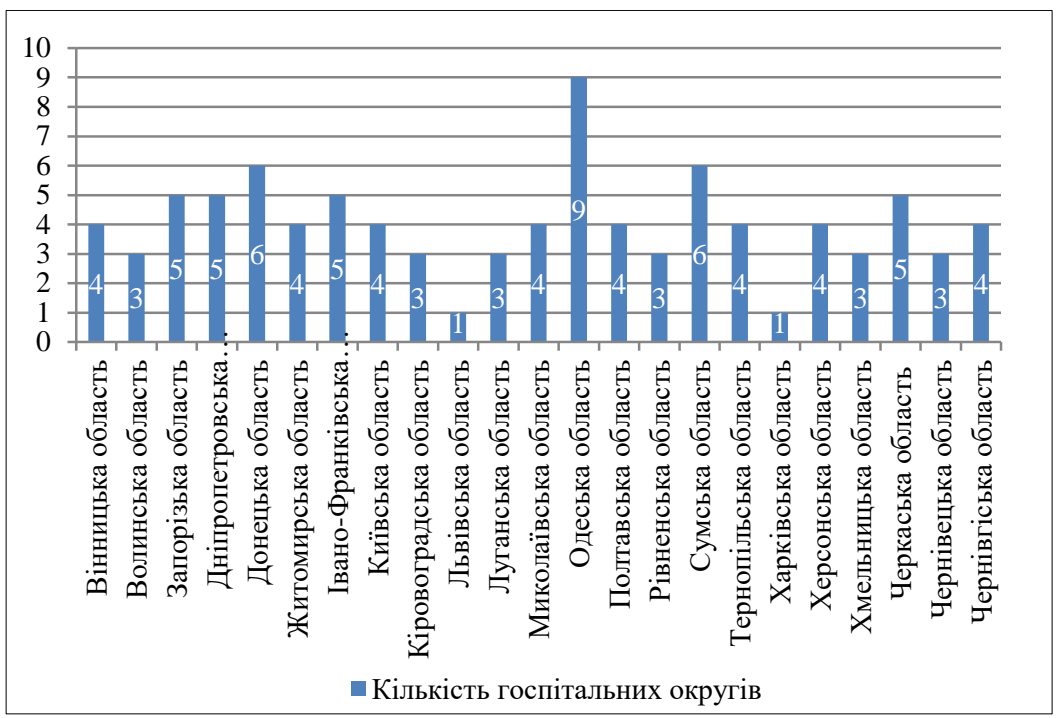

Рис. 4 Кількість госпітальних округів в областях України Джерело: власна розробка автора на основі джерел ${ }^{20,21,22}$.

Звичайно, складність процесу формування госпітальних округів очевидна. 3 метою усунення наявних проблем та неточностей при утворенні госпітальних округів для управлінців та медиків проводяться спеціалізовані тренінги та семінари. На них учасники мають змогу ознайомитися з новими підходами, які розроблені експертами проєкту USAID “Підтримка реформи охорони здоров'я”. Окрім того, під час зазначених тренінгів та семінарів відбуваються роз'яснення того, як правильно аналізувати госпітальну мережу, як визначити багатопрофільні лікарні інтенсивного лікування, адже під час їх утворення необхідно враховувати наявне обладнання та персонал, що без відповідної підготовки практично неможливо ${ }^{23}$.

20 Децентралізація медицини. Госпітальні округи : вебсайт. URL: https://health.decentralization.gov.ua/medical_districts (дата звернення 24.02.2020).

${ }^{21}$ Кудлай Є.М. На Сумщині уряд затвердив госпітальні ради в усіх госпітальних округах. Данкор Онлайн: вебсайт. URL: http://www.dancor.sumy.ua/articles/ community/281790 (дата звернення 24.02.2020).

22 Охорона здоров'я. У Харківській області створено госпітальний округ : вебсайт. URL: https://www.auc.org.ua/novyna/u-harkivskiy-oblasti-stvoreno-gospitalnyyokrug (дата звернення 24.02.2020).

23 Устинов А.В. Госпітальні округи: МО3 представило методологію визначення лікарень інтенсивного лікування. Український медичний часопис : вебсайт. URL: 


\section{4. Перешкоди на шляху процедури \\ утворення госпітальних округів}

Ускладнює процес утворення ефективних госпітальних округів і той факт, що більшість закладів охорони здоров'я в Україні не мають необхідних потужностей для надання якісної вторинної медичної допомоги, зокрема, того самого обладнання, висококваліфікованих кадрів, відповідної інфраструктури, що особливо гостро відображається в сільській місцевості. Очевидно, що без серйозних структурних змін бюджетні кошти й надалі витрачатимуться неефективно, а ресурси держави використовуватимуться нераціонально.

Окрім того, під час проведення одного із семінарів по реформуванню медичної галузі в частині формування госпітальних округів було презентовано Методологію визначення багатопрофільних лікарень інтенсивного лікування, яку було розроблено на основі Чортківського госпітального округу Тернопільської області ${ }^{24}$. Дана методологія дозволяє проводити аналіз госпітальної мережі в межах одного округу на основі наявних даних, поруч із розробкою варіантів рішень щодо визначення лікарень інтенсивного лікування на основі аналізу наявних потужностей та територіальної доступності.

Яскравим свідченням недосконалості процедури утворення госпітальних округів $\epsilon$ наявність фактів активного звернення до Комітету Верховної Ради 3 питань охорони здоров'я народних депутатів, представників від місцевого самоврядування, громадських організацій, колективів медичних закладів, медичних профспілок та окремих громадян, спричинених відсутністю ефективної співпраці між ними ${ }^{25}$.

Паралельно наголошується на недостатності нормативно-правової бази 3 питань створення госпітальних округів. Окрім того, викликає занепокоєння можливість зменшення або повного скасування медичної субвенції з бюджету районам, які не матимуть у своєму розпорядженні багатопрофільної лікарні, що в підсумку спровокує їхнє повне перепрофілювання або скорочення чи закриття. Побоювання втрати

https://www.umj.com.ua/article/136615/gospitalni-okrugi-moz-predstavilo-metodologiyuviznachennya-likaren-intensivnogo-likuvannya (дата звернення 25.02.2020).

${ }^{24}$ Устинов А.В. Госпітальні округи: МО3 представило методологію визначення лікарень інтенсивного лікування. Український медичний часопис : вебсайт. URL: https://www.umj.com.ua/article/136615/gospitalni-okrugi-moz-predstavilo-metodologiyuviznachennya-likaren-intensivnogo-likuvannya (дата звернення 25.02.2020).

${ }^{25}$ Устинов А.В. Госпітальні округи: МO3 представило методологію визначення лікарень інтенсивного лікування. Український медичний часопис : вебсайт. URL: https://www.umj.com.ua/article/136615/gospitalni-okrugi-moz-predstavilo-metodologiyuviznachennya-likaren-intensivnogo-likuvannya (дата звернення 25.02.2020). 
частини фінансування в разі об’єднання декількох районів та міст обласного значення ще більше підсилюється прийнятим рішенням Кабінету міністрів України щодо укрупнення госпітальних округів в областях і створення єдиного госпітального округу області. Інакше кажучи, в одній адміністративно-територіальній одиниці планується створити лише один госпітальний округ.

У той же час дуже проблемно виконати вимоги доступу до вторинної та екстреної медичної допомоги протягом 60 хвилин, особливо в гірських та аграрних районах, зокрема через велику відстань між населеними пунктами, критичним станом автомобільних доріг, особливо в сільській місцевості, відсутність прямого транспортного сполучення, високу вартість проїзду, через рівень цін на паливо та на автобусні квитки тощо. Все це робить практично неможливим доступ пацієнтів 3 інших районів до багатопрофільних лікарень інтенсивного лікування.

Як зазначає міністерка охорони здоров'я 3.П. Скалецька, в результаті довгих дискусій та обговорень, у тому числі з регіональними представниками, було прийнято остаточне рішення сформувати єдиний госпітальний округ у межах однієї області, і вже в його рамках вивчати маршрутну сітку, куди кому їхати до лікарень та яка $є$ можливість задоволення потреб пацієнтів у медичних послугах ${ }^{26}$. Окрім того, 3.П. Скалецька зазначила, що це дозволить відстежити, яким буде маршрут пацієнта та як “виглядатиме" мережа закладів охорони здоров'я. Цей крок - також хороший спосіб визначити, куди саме потрібно спрямувати інвестиції з державного бюджету, які планується виділити в цьому році на закупівлю обладнання. Поруч із цим, міністерством у 2020 році планується побудувати 25-30 сучасних приймальних відділень екстреної медичної допомоги за принципом першочерговості ${ }^{27}$.

Проте, незважаючи на позитивні прогнози керівників процедури реформування діючої мережі медичних закладів, прийняті заходи по усуненню наявних протиріч, напрямки вирішення проблеми своєчасної доставки пацієнтів до медичних закладів так і не були вирішені.

26 Калашник П.І. У кожній області України з'явиться госпітальний округміністерка охорони здоров'я України : вебсайт. URL: https://hromadske.ua/posts/ukozhnij-oblasti-ukrayini-zyavitsya-gospitalnij-okrug-ministerka-ohoroni-zdorovya (дата звернення 25.02.2020).

27 Калашник П.І. У кожній області України 3'явиться госпітальний округміністерка охорони здоров'я України : вебсайт. URL: https://hromadske.ua/posts/ukozhnij-oblasti-ukrayini-zyavitsya-gospitalnij-okrug-ministerka-ohoroni-zdorovya (дата звернення 25.02.2020). 
Адже нормативно вважається, що, для прикладу, 80 км - це та відстань, яку можна проїхати за 60 хвилин, але реально, з урахуванням стану автомобільних доріг, а також наявної кількості особистих автомобілів, у жителів сільської місцевості цей час необхідно збільшувати вдвічі або навіть втричі. Не враховується також можливість стрімкого погіршення погодних умов, що робить деякі транспортні шляхи взагалі непридатними для проїзду. Це все загрожує збільшенням кількості летальних випадків, коли пацієнт об'єктивно не зможе вчасно добратися до медичного закладу. Як варіант вирішення такої ситуації, було запропоновано зменшити вимоги щодо кількості населення, яке повинне обслуговуватись у межах одного госпітального округу, а також радіусу його дії, що на момент написання наукової статті здійснено не було.

Поруч із цим, серед населення виникає занепокоєння 3 приводу надання екстреної медичної допомоги, особливо в тих випадках, коли рахунок іде на хвилини. Так, спочатку, на так званий перехідний період, затверджена мережа опорних медичних закладів, час діяльності яких закінчується через три роки. А от чи буде на цей момент сформована мережа закладів надання екстреної медичної допомоги питання, яке й досі відкрите. На рівні законодавчих актів все виглядає просто й логічно, але наскільки це відповідає реальній ситуації, сказати важко. Окрім того, практично всіма нехтується факт зростання рівня безробіття серед медичних працівників, а також відсутності для них альтернатив працевлаштування ${ }^{28}$. Адже новостворені, укрупнені лікарні, як правило, будуть формуватись із спеціалістів регіону іiі локалізації та із найближчого оточення. В перспективі це може значно вплинути на рівень навантаження на соціальний бюджет, за рахунок зростання виплат по безробіттю, а в глобальному масштабі значно похитнути позиції вітчизняного села та спрямувати міграції сільського населення в напрямку до міста, що з урахуванням тенденцій вимирання українського села може мати критичні наслідки.

Запропоноване урядом створення одного госпітального округу в межах однієї області, на нашу думку, не враховує потреби окремих регіонів, зокрема, наявність потенційно небезпечних об'єктів у зоні їх створення. Прикладом цього може слугувати Рівненська атомна станція, де $\epsilon$ гостра потреба у якомога ближчому розташуванні

28 Мартишин О.О. Госпітальні округи в Україні: проблеми та шляхи їх вирішення. Український медичний часопис : вебсайт. URL: https://www.umj.com.ua/ article/108816/gospitalni-okrugi-v-ukrayini-problemi-ta-shlyahi-yih-virishennya (дата звернення 24.02.2020). 
лікувального закладу ${ }^{29}$. Ще одним моментом, який викликає занепокоєння у членів госпітальних рад та населення регіонів $є$ повна відсутність в Україні закладів інтенсивної терапії, які є обов'язковими складниками госпітального округу, будівництво яких потребує значних витрат коштів та часу ${ }^{30}$.

А заплановане на 2020 рік будівництво лікарень кількістю 25-30 штук у масштабах всієї країни $є$ не достатнім. Саме тому перш ніж повністю перейти на госпітальні округи, необхідно повною мірою сформувати фундамент такого переходу й виробити чітку послідовність кроків, щоб це нововведення стало ефективним кроком на шляху до формування висококваліфікованої та якісної галузі охорони здоров'я в Україні.

\section{ВИСНОВКИ}

Підсумовуючи вищесказане, зазначимо що з кожним роком медична реформа набирає все більших обертів. Те, що планувалось протягом багатьох років, зараз реалізовується на практиці. Складовим елементом цього процесу $є$ створення госпітальних округів у межах областей України. Основною метою їх формування $є$ об'єднання медичних закладів певної місцевості 3 метою підвищення якості наданих ними послуг, а також підвищення рівня їх фінансування, поруч із формуванням ефективної та доступної вторинної (спеціалізованої) ланки та екстреної медичної допомоги по всій території України. Дослідження результатів упровадження цього етапу на практиці свідчить про утворення госпітальних округів майже у всіх областях України, поруч із формуванням в межах регіонів дорадчого органу госпітальних рад, на які накладено обов'язок координувати діяльність госпітального округу, визначати наявні проблеми та напрями їх вирішення, а також розробляти план розвитку на перспективу. 2020 рік вважатиметься переломним для цього етапу реформи, і саме він повинен показати, чи вдасться уряду усунути наявні недоліки системи госпітальних округів на шляху до повноцінного використання переваг від їх створення. Адже, як показує проведене нами дослідження, ще $є$

29 Мартишин О.О. Госпітальні округи в Україні: проблеми та шляхи їх вирішення. Український медичний часопис : вебсайт. URL: https://www.umj.com.ua/ article/108816/gospitalni-okrugi-v-ukrayini-problemi-ta-shlyahi-yih-virishennya (дата звернення 24.02.2020).

30 Мартишин О.О. Госпітальні округи в Україні: проблеми та шляхи їх вирішення. Український медичний часопис : вебсайт. URL: https://www.umj.com.ua/ article/108816/gospitalni-okrugi-v-ukrayini-problemi-ta-shlyahi-yih-virishennya (дата звернення 24.02.2020). 
протиріччя та неточності, які вимагають негайного вирішення, а існування перешкод може значною мірою негативно позначитись на забезпеченні принципів якості та доступності медичних послуг.

\section{АНОТАЦІЯ}

Протягом декількох останніх років на теренах України відбувається активний процес реформування галузі охорони здоров'я, і хоча про реформи говорилось ще в минулому десятилітті, реальні кроки зроблені лише зараз. Так, на підготовчому етапі реформи відбулася перебудова первинної ланки надання медичної допомоги, було започатковано декларації із сімейними лікарями, що дало змогу збільшити фінансування медичних установ, до яких звертається більша кількість пацієнтів. Наступний етап - відбувається реформа вторинної та третинної ланки надання медичної допомоги, поруч із формуванням мережі госпітальних округів. Декларативно процес розпочався ще наприкінці 2016 року прийняттям відповідної постанови Кабінету міністрів України, проте реально цей процес охопив усю територію України лише вкінці 2019 року. Прийняття нових нормативних актів щодо створення та функціонування госпітальних округів зумовило необхідність грунтовнішого вивчення зазначеної тематики. Враховуючи це, в науковій статті визначено законодавчу базу формування госпітальних округів, досліджено підходи до визначення поняття госпітального округу. Окрім того, проаналізовано структуру впливу прийнятих законодавчих актів на розгортання госпітальних округів в Україні. Досліджено склад учасників госпітальних округів, мету та принципи їх формування, порядок визначення переліку госпітальних округів, а також ключові вимоги до їх утворення. Поруч із цим визначено сутність госпітальних рад, порядок відбору учасників госпітальної ради, їх обов'язки, зокрема роль госпітальної ради при формуванні Плану розвитку госпітального округу на $3-5$ років. У науковій статті визначено структуру вищезазначеного плану, порядок його затвердження та звітування за результатами виконання.

Продовжуючи окреслену лінію дослідження, нами визначено кількість створених госпітальних округів на кінець 2019 року в розрізі областей, а також проаналізовано проблеми, 3 якими стикаються регіони під час їх формування. Крім того, окреслено можливі напрямки виправлення наявних недоліків на шляху до повноцінного використання всіх переваг створення та функціонування госпітальних округів. 


\section{ЛІТЕРАТУРА}

1. Децентралізація медицини. Госпітальні округи : вебсайт. URL: https://health.decentralization.gov.ua/medical_districts (дата звернення 24.02.2020).

2. Інформаційне агентство Інтерфакс Україна. Уряд України санкціонував укрупнення госпітальних округів до обласного рівня : вебсайт. URL: https://ua.interfax.com.ua/news/pharmacy/627086.html (дата звернення 24.02.2020).

3. Калашник П.І. У кожній області України з'явиться госпітальний округ-міністерка охорони здоров'я України : вебсайт. URL: https://hromadske.ua/posts/u-kozhnij-oblasti-ukrayini-zyavitsya-gospitalnijokrug-ministerka-ohoroni-zdorovya (дата звернення 25.02.2020).

4. Кудлай С.М. На Сумщині уряд затвердив госпітальні ради в усіх госпітальних округах. Данкор Онлайн : вебсайт. URL: http://www.dancor.sumy.ua/articles/community/281790 (дата звернення 24.02.2020).

5. Мартишин О.О. Госпітальні округи в Україні: проблеми та шляхи їх вирішення. Украӥнський медичний часопис : вебсайт. URL: https://www.umj.com.ua/article/108816/gospitalni-okrugi-v-ukrayiniproblemi-ta-shlyahi-yih-virishennya (дата звернення 24.02.2020).

6. Наказ Міністерства охорони здоров'я України № 165 "Про затвердження примірного положення про госпітальний округ". Сайт Міністерства охорони здоров'я. URL: https://moz.gov.ua/article/ ministry-mandates/nakaz-moz-ukraini-vid-18122017-1621-pro-vnesennjazmin-do-primirnogo-polozhennja-pro-gospitalnij-okrug (дата звернення 24.02.2020).

7. Охорона здоров'я. У Харківській області створено госпітальний округ : веб-сайт. URL: https://www.auc.org.ua/novyna/u-harkivskiyoblasti-stvoreno-gospitalnyy-okrug (дата звернення 24.02.2020).

8. Постанова КМУ № 932 "Про затвердження порядку створення госпітальних округів" (Постанова втратила чинність на підставі Постанови КМ № 1074 від 27.11.2019). Верховна Рада Украӥни. Офіиійний сайт. Нормативні акти. URL: https://zakon.rada.gov.ua/ laws/show/932-2016-\%D0\%BF (дата звернення 24.02.2020).

9. Постанова КМУ № 1074 “Деякі питання створення госпітальних округів”. Нормативні акти. Верховна Рада Украйни. Офіційний сайт. URL: https://zakon.rada.gov.ua/laws/show/1074-2019-\%D0\%BF (дата звернення 24.02.2020).

10. Розпорядження КМУ № 23-Р “Про затвердження переліку опорних закладів охорони здоров'я у госпітальних округах на період до 2023 року". Верховна Рада Украйни. Офіиійний сайт. Нормативні акти. 
URL: https://www.kmu.gov.ua/npas/pro-zatverdzhennya-pereliku-opornihzakladiv-ohoroni-zdorovya-u-gospitalnih-okrugah-na-period-do-2023-roku23-150120 (дата звернення 24.02.2020).

11. Розпорядження КМУ № 1013-р “Про схвалення концепції реформи фінансування системи охорони здоров'я" зі змінами та доповненнями станом на 30.11.2016 року. Нормативні акти. Верховна Рада Украӥни. Офіиійний сайт. URL: https://zakon.rada.gov.ua/laws/ show/1013-2016-\%D1\%80 (дата звернення 24.02.2020).

12. Устинов А.В. Госпітальні округи: МО3 представило методологію визначення лікарень інтенсивного лікування. Украӥнський медичний часопис : вебсайт. URL: https://www.umj.com.ua/article/ 136615/gospitalni-okrugi-moz-predstavilo-metodologiyu-viznachennyalikaren-intensivnogo-likuvannya (дата звернення 25.02.2020).

\section{Information about authors:}

Hbur Z. V.,

Doctor of Science in Public Administration, Professor at the Department of Health Management Shupyk National Medical Academy of Postgraduate Education

9, Dorogozhyzkaja str., Kyiv, 04112, Ukraine Chief Specialist of the Ministry of Finance of Ukraine 11 Mezhigirska str., Kyiv, 04071, Ukraine

Stovban N. P., Candidate of Medical Sciences, Associate Professor at the Department of Phthisiology and Pulmonology with the Course of Occupational Diseases,

Deputy General Director Communal non-commercial enterprise "Ivano-Frankivsk Regional Clinical Infectious Diseases Hospital of the Ivano-Frankivsk Regional Council" 66, Hetmana Sahaidachnoho str., Ivano-Frankivsk, 76000, Ukraine 